\section{Carbon Dioxide Injury and Flesh Softening Following High-temperature Conditioning in Peaches}

\author{
George D. Nanos and F. Gordon Mitchell \\ Department of Pomology, University of California, Davis, CA 95616
}

Additional index words. Prunus persica, internal breakdown, low-oxygen atmospheres

\begin{abstract}
High-temperature controlled-atmosphere (high $\mathrm{CO}_{2} / \mathrm{low} \mathrm{O}_{2}$ ) conditioning was investigated as a possible treatment to delay the incidence of internal breakdown of peaches and nectarines (Prunus persica $\mathbf{L}$. Batsch) during subsequent cold storage. Maintaining an atmosphere of $5 \%$ to $15 \% \mathrm{CO}_{2}$ added to air or to $1 \%$ to $5 \% \mathrm{O}_{2}$ while conditioning peaches for 2 days at $20 \mathrm{C}$ partially prevented fruit ripening (compared to fruit conditioned in air), as measured by flesh softening and loss of green pigment, while no off-flavors were detected. Conditioning of peaches at $20 \mathrm{C}$ for $\mathbf{4}$ days in air or in air $+20 \% \mathrm{CO}_{2}$ was detrimental to fruit quality, as indicated by flesh softening or detection of off-flavors.
\end{abstract}

High-temperature controlled-atmosphere (CA) conditioning is currently being investigated in our laboratory as a possible treatment to delay the incidence and reduce the severity of internal breakdown of peaches and nectarines during subsequent cold storage. The relative tolerance to short-term exposure to high $\mathrm{CO}_{2}$ has been examined for various commodities (Allen, 1939; Hatton et al., 1975; Lange and Fica, 1984; Wang and Mellenthin, 1975; Wills et al., 1979). Shortterm exposure to $\mathrm{CA}$ before storage lowered respiration rates and retained flesh firmness of many commodities (Bramlage et al., 1977; Herner, 1987; Kader, 1986; Lange and Fica, 1984). Increased $\mathrm{CO}_{2}$ appears to be more effective than decreased $\mathrm{O}_{2}$ in firmness retention (Kader, 1986).

The concentrations of $\mathrm{CO}_{2}$ and $\mathrm{O}_{2}$ that cause injury have been reported for various fruits and vegetables (Kader and Morris, 1977; Lougheed, 1987; Wills et al., 1979). Duration under $\mathrm{CA}$ and holding temperature may influence the concentrations at which $\mathrm{CO}_{2}$ becomes injurious to a commodity (Wang and Mellenthin, 1975). Observed $\mathrm{CO}_{2}$ injury symptoms include: external and internal browning, off-flavors and odors, and changes in susceptibility to disorders (Herner, 1987; Lougheed, 1987). All CA studies with stone fruit have been performed at low temperature (Anderson and Hardenburg, 1977). It was unknown how these fruit would react to high $\mathrm{CO}_{2}$ levels at $20 \mathrm{C}$.

We attempted to determine whether certain levels of $\mathrm{CO}_{2}$ and $\mathrm{O}_{2}$ would slow fruit ripening and flesh softening during conditioning without causing significant injury. The effects of short exposure to various $\mathrm{CO}_{2}$ and $\mathrm{O}_{2}$ levels at $20 \mathrm{C}$ were investigated on 'Suncrest' and 'Elegant Lady' peaches.

Fruit were obtained from an orchard near

Received for publication 23 Mar. 1990. The cost of publishing this paper was defrayed in part by the payment of page charges. Under postal regulations, this paper therefore must be hereby marked advertisement solely to indicate this fact.
Winters, Calif., and were sorted for uniformity of size (7 to $9 \mathrm{~cm}$ in diameter) and maturity (immature and soft fruit were eliminated, fruit with uniform background color were used) and freedom from mechanical injury, insect and disease damage, and cracks. Fruit were dipped for $30 \mathrm{sec}$ in a fungicidal solution containing $0.6 \mathrm{~g}$ methyl-1-(butylcarbamoyl)-2-benzimidazolecarbamate (benomyl)/liter plus $1.2 \mathrm{~g}$ 2,4-dichloro-6nitroaniline (botran)/liter. The fruit were then placed in plastic drums, exposed to conditioning atmospheres shown in Table 1, and subsequently stored in boxes with loosely closed polyethylene liners in air at $0 \mathrm{C}$. The CA conditions were achieved using a continuous-flow gas mixing system. Since the 'Suncrest' peaches did not show any injury when $15 \% \mathrm{CO}_{2}$ was used during conditioning, higher $\mathrm{CO}_{2}$ levels were used during the subsequent 'Elegant Lady' experiment. The concentrations of $\mathrm{O}_{2}$ and $\mathrm{CO}_{2}$ were monitored using a Carle gas chromatography (Model 111; Carle Instruments, Anaheim, Calif.) equipped with a thermal conductivity detector. Gases were maintained within $\pm 0.2 \%$ of the desired concentrations.

Quality evaluations were performed after the fruit were taken out of cold storage and again following ripening. The loss of greenness, expressed as the Gardner 'a' value, was measured in a representative area of the fruit surface (without red coloration, whenever possible) using a Gardner XL-23 Tristimulus calorimeter (Gardner Laboratory, Bethesda, Md.). The 'a' value increases as fruit yellows. Skin was removed from the two cheeks, and two flesh firmness measurements per fruit were made using a U.C. firmness tester (Western Industrial Supply Co., San Francisco) with an 8-mm-diameter cylindrical tip. For all fruit evaluations, there were three replications per treatment and five fruit per replication.

Respiration and ethylene production of six randomly selected fruit were determined following the 2- and 4-day conditioning treatments. The fruit were placed individually in jars ventilated with a flowing air stream of $\approx 2.5$ liters $\cdot \mathrm{h}^{-1}$. The concentration of $\mathrm{CO}$, in the samples was measured with a Horiba infrared $\mathrm{CO}_{2}$ gas analyzer (Model SX-2, PIR2000R; Horiba Instruments, Irvine, Calif.), and the concentration of $\mathrm{C}_{2} \mathrm{H}_{4}$ with a Carle gas chromatography (Model 211; Carle Instruments) equipped with a flame ionization detector.

Following the CA treatments, the fruit were stored at $0 \mathrm{C}$ for 8 ('Suncrest') or 9 days ('Elegant Lady'). After storage, the fruit were allowed to reach room temperature $(\approx 22 \mathrm{C})$. One-half of the fruit of each sample were evaluated for quality. The remaining fruit were evaluated after 4 to 5 days at 20C. In addition to the quality criteria described above, fruit from the CA treatments were also examined for surface pitting. They were then cut transversely to the plane of the suture, and the extent of flesh browning and' 'bleeding" (red pigment in the mesocarp area) was measured. An informal taste panel consisting of four tasters evaluated peach flavor, presence of off-flavors, and overall acceptability. After ripening of the remaining fruit, flesh firmness was measured, and the external and internal appearance and flavor were evaluated. One factor analysis of variance was calculated, and Duncan's mean separation and LSD values are presented.

For the 'Suncrest' peaches, the skin color (Gardner 'a' value) before ripening was greenest (but not always significantly) in the OC control (no conditioning), $1 \% 0_{2}+5 \%$ $\mathrm{CO}_{2}$ conditioning at $20 \mathrm{C}$ for 2 days, and $15 \%$ $\mathrm{CO}_{2}$ conditioning at $20 \mathrm{C}$ for 2 days treatments (Table 1). For the 'Elegant Lady' peaches, the 0C control fruit were greenest (Table 1). Thus, conditioning at 20C in air for the indicated duration and conditions did not inhibit normal color development. These results agree with previously reported work (Isenberg, 1979).

The treatments did not affect the following characteristics: flesh color (Tristimulus calorimeter 'a' value), soluble solids content, titratable acidity, and $\mathrm{pH}$ (data not shown).

'Suncrest' and 'Elegant Lady' peaches previously conditioned for 2 days in air (then stored for 8 to 9 days at $0 \mathrm{C}$ ) softened excessively; 'Suncrest' fruit conditioned for 4 days in air was even softer (Table 1). All 'Suncrest' peaches that were conditioned for 4 days were significantly softer than those conditioned for 2 days, except that those conditioned for 2 or 4 days in $1 \% \mathrm{O}_{2}+5 \%$ $\mathrm{CO}_{2}$ were of equal firmness. When 'Elegant Lady' peaches were conditioned for 4 days in $15 \% \mathrm{CO}_{2}$, the flesh firmness remained high. In general, the nonconditioned fruit, and those conditioned in $1 \% \mathrm{O}_{2}$ or $>15 \%$ $\mathrm{CO}_{2}$, were most firm after storage, but were not significantly different from those in most other treatments. These results agree with previously published work with strawberries, bushberries, apples, and other horticultural commodities (Kader, 1986; Looney, 1975).

Flesh firmness measurements taken after 4 to 5 days ripening in air at $20 \mathrm{C}$ were similar for all treatments (data not presented). 
Table 1. Effect of various atmospheres applied during 20C conditioning followed by $0 \mathrm{C}$ air storage on the external color and flesh firmness of 'Suncrest' and 'Elegant Lady' peaches. ${ }^{2 .}$

\begin{tabular}{|c|c|c|c|c|c|c|c|c|c|}
\hline \multicolumn{5}{|c|}{ Suncrest } & \multicolumn{5}{|c|}{ Elegant Lady } \\
\hline \multicolumn{3}{|c|}{ Conditioning treatments } & \multirow{2}{*}{$\begin{array}{l}\text { Skin color } \\
\text { ('a' value) }\end{array}$} & \multirow{2}{*}{$\begin{array}{l}\text { Flesh firmness } \\
(\mathrm{N})\end{array}$} & \multicolumn{3}{|c|}{ Conditioning treatments } & \multirow{2}{*}{$\begin{array}{l}\text { Skin color } \\
\text { ('a' value) }\end{array}$} & \multirow{2}{*}{$\begin{array}{l}\text { Flesh firmness } \\
(\mathrm{N})\end{array}$} \\
\hline $\mathrm{O}_{2}(\%)$ & $\mathrm{CO}_{2}(\%)$ & Days & & & $\mathrm{O}_{2}(\%)$ & $\mathrm{CO}_{2}(\%)$ & Days & & \\
\hline \multicolumn{3}{|l|}{ At harvest } & $10.1 \mathrm{~b}$ & $58.3 \mathrm{a}$ & \multicolumn{2}{|c|}{ At harvest } & & $8.2 \mathrm{c}$ & $66.0 \mathrm{a}$ \\
\hline 21 & 0 & 0 & $11.5 \mathrm{~b}$ & $61.1 \mathrm{a}$ & 21 & 0 & -0 & $19.6 \mathrm{~b}$ & $66.0 \mathrm{a}$ \\
\hline 21 & 0 & 2 & $17.5 \mathrm{a}$ & $31.6 \mathrm{~d}$ & 21 & 0 & 2 & $28.2 \mathrm{a}$ & $44.3 \mathrm{~b}$ \\
\hline 21 & 0 & 4 & $17.3 \mathrm{a}$ & $13.6 \mathrm{e}$ & 1 & 5 & 2 & $24.1 \mathrm{ab}$ & $65.6 \mathrm{a}$ \\
\hline 1 & 5 & 2 & $11.6 \mathrm{~b}$ & $50.9 \mathrm{bc}$ & 1 & 5 & 4 & $24.6 \mathrm{ab}$ & $63.4 \mathrm{a}$ \\
\hline 1 & 5 & 4 & $15.6 \mathrm{ab}$ & $51.5 \mathrm{bc}$ & 5 & 5 & 2 & $27.3 \mathrm{a}$ & $63.2 \mathrm{a}$ \\
\hline 5 & 5 & 2 & $15.9 \mathrm{ab}$ & $49.2 \mathrm{bc}$ & 20 & 5 & 2 & $27.9 \mathrm{a}$ & $56.3 \mathrm{a}$ \\
\hline 5 & 5 & 4 & $17.3 \mathrm{a}$ & $33.4 \mathrm{~d}$ & 19 & 10 & 2 & $22.9 \mathrm{ab}$ & $62.9 \mathrm{a}$ \\
\hline 20 & 5 & 2 & $16.3 \mathrm{ab}$ & $33.4 \mathrm{c}$ & 18 & 15 & 2 & $23.8 \mathrm{ab}$ & $63.0 \mathrm{a}$ \\
\hline 19 & 10 & 2 & $18.4 \mathrm{a}$ & $46.4 \mathrm{C}$ & 18 & 15 & 4 & $26.6 \mathrm{a}$ & $54.6 \mathrm{a}$ \\
\hline 19 & 10 & 4 & $17.8 \mathrm{a}$ & $35.7 \mathrm{~d}$ & 17 & 20 & 2 & $29.3 \mathrm{a}$ & $64.4 \mathrm{a}$ \\
\hline 18 & 15 & 2 & $12.1 \mathrm{~b}$ & $55.8 \mathrm{ab}$ & 15 & 30 & 2 & $27.8 \mathrm{a}$ & $65.2 \mathrm{a}$ \\
\hline \multicolumn{3}{|c|}{ L S $D_{P=0.05^{x}}$} & 4.4 & 7.6 & & & & 5.5 & 10.1 \\
\hline
\end{tabular}

${ }^{2}$ Measurements were taken after 8 and 9 days storage at 0C for 'Suncrest' and 'Elegant Lady', respectively.

${ }^{y}$ Measurements followed by the same letter-are not significantly different.

${ }^{x}$ With one factor analysis of variance over treatment.

Table 2. Effect of various atmospheres applied during 20C conditioning followed by 0C air storage on off-flavor and mealiness development of 'Suncrest' and 'Elegant Lady' peaches.

\begin{tabular}{|c|c|c|c|c|c|c|c|c|}
\hline \multicolumn{4}{|c|}{ Suncrest $^{2}$} & \multicolumn{5}{|c|}{ Elegant Lady } \\
\hline \multicolumn{3}{|c|}{ Conditioning treatments } & \multirow[b]{2}{*}{ Off-flavor ${ }^{x}$} & \multicolumn{3}{|c|}{ Conditioning treatments } & \multirow[b]{2}{*}{ Off-flavor } & \multirow[b]{2}{*}{ Mealy } \\
\hline $\mathrm{O}_{2}(\%)$ & $\mathrm{CO}_{2}(\%)$ & Days & & $\mathrm{O}_{2}(\%)$ & $\mathrm{CO}_{2}(\%)$ & Days & & \\
\hline 21 & 0 & 0 & & 21 & 0 & 0 & & \\
\hline 21 & 0 & 2 & & 21 & 0 & 2 & & \\
\hline 21 & 0 & 4 & & 1 & 5 & 2 & & \\
\hline 1 & 5 & 2 & & 1 & 5 & 4 & ++ & \\
\hline 1 & 5 & 4 & ++ & 5 & 5 & 2 & ++ & \\
\hline 5 & 5 & 2 & & 20 & 5 & 2 & & \\
\hline 5 & 5 & 4 & + & 19 & 10 & 2 & & \\
\hline 20 & 5 & 2 & & 18 & 15 & 2 & + & \\
\hline 19 & 10 & 2 & & 18 & 15 & 4 & ++ & \\
\hline 19 & 10 & 4 & ++ & 17 & 20 & 2 & + & ++ \\
\hline 18 & 15 & 2 & & 15 & 30 & 2 & ++ & ++ \\
\hline
\end{tabular}

${ }^{2}$ Ratings were taken after 8 days storage at $0 \mathrm{C}$ followed by 5 days at $20 \mathrm{C}$.

${ }^{y}$ Ratings were taken after 9 days storage at $0 \mathrm{C}$ followed by 4 days at $20 \mathrm{C}$.

${ }^{x}$ Ratings of off-flavor and mealiness: $+=$ moderate, $++=$ severe.

This observation suggests that the CA conditioning treatment had no residual effect on fruit ripening. Published work suggests that a residual effect of CA on ripening is often, but not always, observed (Kader, 1986).

Production rates for $\mathrm{CO}_{2}$ and $\mathrm{C}_{2} \mathrm{H}_{4}$ of individual fruit immediately after the conditioning treatment were not significantly affected by CA treatments (not shown). This result contrasts with the generally recognized effects of high $\mathrm{CO}_{2}$ on inhibiting $\mathrm{C}_{2} \mathrm{H}_{4}$ production and action and on slowing respiratory activity of fruit (Chaves and Tomas, 1984; Herner, 1987).

Fruit conditioned in reduced $\mathrm{O}_{2}$ and elevated $\mathrm{CO}_{2}$ for 4 days had developed off-flavors (Table 2). Both mealiness and off-flavors were detected in 'Elegant Lady' fruit at $\mathrm{CO}_{2}$ concentrations higher than $15 \%$.

Peaches that were conditioned for 2 or 4 days in air at 20C became excessively soft and showed substantial loss of external greenness. Softening and off-flavor development were unacceptable with fruit conditioned under $\mathrm{CA}$ for 4 days; thus, conditioning for 4 days at $20 \mathrm{C}$ is precluded. Levels of $\mathrm{CO}_{2}$ higher than $15 \%$ during conditioning were detrimental to fruit quality even after 2 days of conditioning. We conclude that conditioning of peaches at $20 \mathrm{C}$ for 2 days should be accompanied by an atmosphere containing $5 \%$ to $15 \% \mathrm{CO}_{2}$ added to air or to $1 \%$ to $5 \% \mathrm{O}_{2}$, so that flesh firmness and changes in greenness are partially inhibited, without detrimental effects on fruit flavor. The value of these conditioning treatments in relation to their effect on the incidence and severity of internal breakdown of peaches during subsequent cold storage remains to be evaluated.

\section{Literature Cited}

Allen, F.W. 1939. Carbon dioxide investigations: Influence of carbon dioxide atmospheres upon cherries, plums, peaches, and pears under simulated transit conditions. Proc. Amer. Soc. Hort. Sci. 37:467-472.

Anderson, R.E. and R.E. Hardenburg. 1977. Results and recommendations on controlled and modified atmosphere storage and transport of stone fruits, p. 235-241. In: D.H. Dewey (ed.). Controlled atmospheres for storage and transport of perishable agricultural commodities. Hort. Rpt. 28, Michigan State Univ., East Lansing.
Bramlage, W. J., P.H. Bareford, G.D. Blanpied, D.H. Dewey, S. Taylor, S.W. Porritt, E.C. Lougheed, W.H. Smith, and F.S. McNicholas. 1977. Carbon dioxide treatments for 'McIntosh' apples before CA storage. J. Amer. Soc. Hort. Sci. 102:658-662.

Chaves, A.R. and J.O. Tomas. 1984. Effect of a brief $\mathrm{CO}_{2}$ exposure to ethylene production. Plant Physiol. 76:88-91.

Hatton, T. T., R.H. Cubbedge, and W. Grierson. 1975. Effects of prestorage carbon dioxide treatments and delayed storage on chilling injury of 'Marsh' grapefruits. Proc. Fla. State Hort. Soc. 88:335-338

Herner, R.C. 1987. High $\mathrm{CO}_{2}$ effects on plant organs, p. 239-253. In: J. Weichmann (ed.). Postharvest physiology of vegetables. Marcel Dekker, New York.

Isenberg, M.F.R. 1979. Controlled atmosphere storage of vegetables. Hort. Rev. $1: 337-394$.

Kader, A.A. 1986. Biochemical and physiological basis for effects of controlled and modified atmospheres on fruits and vegetables. Food Technol. 40(5):99-100, 102-104.

Kader, A.A. and L.L. Morris. 1977. Relative tolerance of fruits and vegetables to elevated $\mathrm{CO}_{2}$ and reduced $\mathrm{O}_{2}$ levels, p. 260-265. In: D.H. Dewey (cd.). Controlled atmospheres for storage and transport of perishable agricultural commodities. Hort. Rpt. 28, Michigan State Univ., East Lansing.

Lange, E. and J. Fica. 1984. The storage response of 'Golden Delicious' and 'Jonathan' apples to ethylene removal from controlled atmospheres and to prestorage short term high $\mathrm{CO}_{2}$ treatment. Fruit Sci. Rpts. (Poland) 11:159-168.

Looney, N.E. 1975. Control of ripening in 'McIntosh' apples. II. Effect of growth regulators and $\mathrm{CO}_{2}$ on fruit ripening, storage behaviour, and shelf life. J. Amer. Soc. Hort. Sci. 100:332-336

Lougheed, E.C. 1987. Interactions of oxygen, carbon dioxide, temperature, and ethylene that may induce injuries in vegetables. HortScience 22:791-794.

Wang, C.Y. and W.M. Mellenthin. 1975. Effect of short-term high $\mathrm{CO}_{2}$ treatment on storage of 'd'Anjou' pear. J. Amer. Soc. Hort. Sci. 100:492-495

Wills, R. B. H., P. Wimalasiri, and K.J. Scott. 1979. Short pre-storage exposures to high carbon dioxide or low oxygen atmospheres for the storage of some vegetables. HortScience 14:528530 . 